\title{
Effect of Copper Toxicity on Hematological Parameters to Fresh Water Fish Cyprinus Carpio(Common Carp)
}

\author{
${ }^{1}$ Yesudass Thangam , ${ }^{2}$ Sekar Jayaprakash, ${ }^{3}$ Muthusamy Perumayee \\ Assistant Professor, \\ J.K.K.Nattraja College of Arts and Science, Kumarapalayam, Namakkal (Dt)
}

\begin{abstract}
The present study was to evaluate the toxicity of copper in the blood cells of fresh water fish Cyprinus carpio. Ingestion of copper compounds cause anemia and other blood cell abnormalities, may produce systemic toxic effects to the kidney and liver and central nervous system excitation followed by depression. Causes respiratory tract irritation with possible burns. Chronic: Prolonged or repeated eye contact may cause conjunctivitis. Table 2 and Fig. 1 Reveal the changes in red blood cell count of the blood of fish Cyprinus carpio exposed to sublethal concentration of copper exposed for 35 days. The RBC count was decreased throughout the study period when compared to the control showing a minimum percent decrease of 2.22 at the end of $7^{\text {th }}$ day and a maximum percent decrease of 18.36 at the end of $35^{\text {th }}$ day. Decrease in RBC count in copper exposed for $7^{\text {th }}, 14^{\text {th }}, 21^{\text {st }}, 28^{\text {th }}$, and $35^{\text {th }}$ days, the percent observed was $-2.22,-6.52,-10.63$, 14.58, -18.36. Changes in the leucocyte count of fish Cyprinus carpio exposed to sublethal concentration of copper for 35 days were presented in Table 3 and Fig 2. During the above exposure period WBC count was decreased throughout the study period showing a percent decrease of $-48.51,-53.09,-67.63,-70.43,-74.82$ at the end of $7^{\text {th }}, 14^{\text {th }}, 21^{\text {st }}, 28^{\text {th }}$, and $35^{\text {th }}$, days respectively. However, WBC count was declined showing a minimum percent decrease of -48.51 at the end of the $7^{\text {th }}$, day and maximum percent decrease -74.82 at the end of $35^{\text {th }}$ day. Table 4. and Fig 3. Represent the data on changes in the hemoglobin content of the fish Cyprinus carpio exposed to sublethal concentration of copper for 35 days. The hemoglobin content in the copper exposed fish was found to be decreased when compared to the control showing the percent decrease of -15.64, -26.59, $25.60,-23.36,-11.73$ for $7,14,21,28,35$ days. However, this results shows a minimum percent decrease at $35^{\text {th }}$ day, showing a percent decrease of -11.73 and a maximum percent decrease at $14^{\text {th }}$ day showing a percent decrease of -26.59 in copper exposed fish.
\end{abstract}

Keywords: Cyprinus carpio, Copper, Hematological parameters

\section{Introduction}

Fish are an important component of human nutrition, and those from contaminated sites present a potential risk to human health. Since fish occupy the top of the aquatic food chain, they are suitable bioindicators of metal contamination. Metals are well-known inducers of oxidative stress, and assessment of oxidative damage and antioxidant defences in fish can reflect metal contamination of the aquatic environment (Livingstone, 2003). Metals, especially heavy metals, like copper are important contaminants of aquatic environments worldwide. Metal pollution has increased with the technological progress of human society. Industry, mining, advanced agriculture, household waste, and motor traffic are all among the activities considered to be major sources of metal pollution. Metals can accumulate in aquatic organisms, including fish, and persist in water and sediments (Luoma and Rainbow, 2008). Speciation of metals, their solubility and complexation, are important factors that influence the toxicity of metals in the aquatic environment. The amount of dissolved metal strongly depends on water $\mathrm{pH}$. The interaction of metals can alter their toxic effects on aquatic organisms both positively and negatively (Jezierska and Witeska, 2001). Different modes of exposure to metals also play a role in metal toxicity. Fish take up metals through the gills, digestive tract and body surface (Tao et al., 2001; Kamunde et al., 2002).

Copper are absorbed through gills and gastrointestinal track by fish organisms, free of the uptake way they are chiefly accumulated in metabolically active tissues such as liver and kidney. Gills are indirect contact with the outer environment with the pollutants. Liver acts in the transformation of basic nutrients and in detoxification on storage of toxic materials. The interference in the gas exchange, nitrogenous waste excretion, acid-base and ionic stability due to the change in water $\mathrm{pH}$ cause stress in fish affecting its body physiology and growth (Roja sadat jalali Mottahari et al., 2013). Large concentrations of $\mathrm{CuSO}_{4}$ damage the gill epithelium, hematopoietic tissues, kidney, spleen and liver of fish (Nussey et al ., 1995; Mazon et al ., 2002; Figueiredo -Fernandes et al., 2007). Consequently, they alter the blood parameters (Nussey et al ., 1995a; Mazon et al ., 2002; Tavares-Dias et al ., 2002; Carvalho and Fernandes, 2006) and osmoregulation (Nussey et al. , 1995a; Mazon et al ., 2002; Carvalho and Fernandes, 2006; Singh et al ., 2008). Immunosuppression can also be observed (Mazon et al ., 2002; Tavares-Dias et al ., 2002), due to the fact that monocytes and neutrophils 
are sensitive to heavy metals (Witeska and Wakulska, 2007). Blood assessment constitutes an important tool to evaluate the fish health and may vary according to toxicants (Nussey et al. , 1995a, b, c; Mazon et al., 2002; Singh et al ., 2008).

Copper $\left(\mathrm{Cu}^{++}\right)$toxicity is influenced by water alkalinity and hardness; hence, when used in water with low concentrations of $\mathrm{CaCO}_{3}$, the ion $\mathrm{Cu}^{++}$may cause physiological changes in fish. The cupric ion interferes in the linking of ionic regulatory proteins by obstructing their regulatory function (Adhikari, 2003). In fish, $\mathrm{Cu}^{++}$is an essential trace metal for metabolic functions. However, it is potentially toxic when the internal available concentration exceeds the capacity of physiological detoxification processes (Figueiredo -Fernandes et al ., 2007). Fish exposed to environmental pollutants exhibit a variety of physiological responses, including blood balance disturbances (Booth et al.,1988). The evaluation of hematological characteristics in fish has become an important means of understanding normal and pathological processes and toxicological impacts (Sudova et al.,2009). $\mathrm{CuSO}_{4}$ at various concentrations exerted a certain influence on some of the blood indices studied. In this study, the main hematological response of Cyprinus carpio fingerling to the sublethal concentration of $\mathrm{CuSO}_{4}$ was a significantly lower, and decrease in the $\mathrm{RBC}, \mathrm{Hb}$, than to the control group. Similar results were found in Channa punctatus that exposure to sublethal concentration of $\mathrm{CuSO}_{4}$ and reduced the $\mathrm{RBC}, \mathrm{Hb}$ concentration.. In C. macropomum, it was observed that the number of $\mathrm{RBC}$ decreased after treatment with various concentrations of $\mathrm{CuSO}_{4}$ (Griffin et al.,1999).

Various changes in the indices of red blood cells noticed in various fish species depending on the concentration of copper and time of exposure. In acute tests, when Carp and Rainbow trout yearling were exposed to copper concentrations close to LC50, there were established increased levels of erythrocyte count, haemoglobin concentration (Svobodova et al., 1994). $0.25 \mathrm{mg} / 1$ of copper also increased haemoglobin concentration in the blood of Indian catfish (Heteropneustes fossilis Bloch) (Singh and Reddy, 1990). An increase in the levels of haemoglobin concentrations was observed in fish after 96-hour exposure to $3 \mathrm{mg} / 1$ of copper (Mishra and Srivastava, 1980). An increase in haemoglobin and haematocrit concentrations was determined after 24-hour exposure of Oreochromis mossambicus (Peters) fish to much lower concentrations of copper (100 and $200 \mathrm{mkg} / \mathrm{l})$ (Cyriac et al.,1989). However no changes in the erythrocyte count were registered during acute 96 -hour tests while investigating the effect of copper concentration of $0.125 \mathrm{mg} / 1$ on rainbow trout (Oncorhynchus mykiss). An increase in erythrocytes was observed only in several fish after they had been exposed to the copper concentration of $0.5 \mathrm{mg} / \mathrm{l}$ (Vosylienë, 1996).

Significant increase and decrease in erythrocyte count were determined by various authors in haemoglobin, that acute 48-hour exposure of catfish (Clarias garlepinus) from Clariidae family to background copper concentrations induce a significant decrease in the count of erythrocytes as well as haemoglobin concentrations, although after 48-hour exposure these two indices slightly increase (Van vuren et al., 1994). Haemolysis and anaemia were determined in catfish (Clarias lazera) after 96-hour exposure to $3.2 \mathrm{mg} / 1 \mathrm{of}$ copper (El-Domiaty, 1987). Dick and Dixon(1984) established a statistically reliable decrease of erythrocytes in the blood of trout (Salmo gairdneri) after 24-hour exposure to $0.301 \mathrm{mg} / \mathrm{l}$ of copper. Meanwhile, a long-term exposure (16 weeks) did not have any significant effect on the concentration of erythrocytes (Mckim et al.,1970). During a long-term exposure (3 months), $0.1 \mathrm{mg} / \mathrm{l}$ of copper slightly affected the count of erythrocytes in the blood of trout, although there was observed a decrease in the haemoglobin concentration as well. However, while exposing fish to a doubly stronger concentration of copper $(0.2 \mathrm{mg} / \mathrm{l})$, the tendency of decrease in both these indices was observed (Vosylienë,1996*). Lower copper concentrations of 0.49 and $0.104 \mathrm{mkg} / \mathrm{l}$ increased the concentration of haemoglobin in the blood of brown bullhead (Ictalurus nebulosus Lesueur) after 30-day exposure (Christensen et al.,1972). Low copper concentrations (24, 39, $67 \mathrm{mkg} / \mathrm{l})$ also caused an increase in the erythrocyte count, concentration of haemoglobin (Mckim et al.,1970).

During the acute tests the yearlings of Carp and Trout were exposed to copper concentrations close to lethal, a significant decrease was established in the leucocyte counts (especially small ones) and an increase in the neutrophil count (Svobodova et al., 1994). During acute exposure to sublethal copper concentrations $(0.301$ $\mathrm{mg} / \mathrm{l}$ ), a significant decrease was established in the concentration of leucocytes, mostly due to a decrease in the count of lymphocytes. Meanwhile, the same concentration slightly affected the count of leucocytes after 16week exposure, however there was observed a decrease of neutrophils (Dick, Dixon, 1985). However after 2 hours exposure of catfish (Clarias garlepinus, Clariidae) to a background copper concentration, the count of leucocytes increased considerably (Van Vuren et al.,1994). Copper concentrations had a significant effect on the changes in leucocyte count in the blood of rainbow trout: if in acute tests $0.125 \mathrm{mg} / \mathrm{l}$ of copper did not affect significantly the leucocyte count during acute tests, $0.5 \mathrm{mg} / 1$ of copper decreased it dramatically (Vosylienë, 1996*). During long-term exposure (3 months), 0.1 and $0.2 \mathrm{mg} / 1$ concentrations of copper decreased the leucocyte count in blood (Vosylienë,1996). After 21-day exposure of Rainbow trout to copper in soft water, the concentration of lymphocytes in blood decreased under the influence of much lower concentrations of copper (6.4, 16.0, and 26.9 g/l) (Dethloff and Bailey, 1998). 
Copper is extremely toxic to fish and causes tissue damages in gills and hematopoietic organs. Gills are the primary target organ for the toxic action of copper (Mazon et al ., 2002, Figueiredo -Fernandes et al ., 2007). Therefore, these changes in both tissues lead to hematological disturbances (Nussey et al ., 1995a, b, c; Mazon et al ., 2002; Carvalho and Fernandes, 2006). Copper inhibits the excretion of ammonia through the gills; increases cortisol levels, stimulates the protein catabolism and increases levels of blood ammonia (Griffin et al., 1999. Grossell et al., 2002). Copper undergoes complex speciation in natural waters; some species are bioavailable (free $\mathrm{Cu}_{2}{ }^{+}$and $\mathrm{Cu}^{+}$ions), while others are not. Only bioavailable forms of copper are considered to be toxic to exposed organisms. The bioavailability, biodistribution to various parts of the organism, and bioaccumulation of copper are dramatically influenced by water chemistry. Therefore, water $\mathrm{pH}$, hardness, organic content, and salinity play important roles in copper-induced toxicity. Maintaining target concentration levels of copper can be challenging. Keeping copper concentrations high enough is difficult for many reasons. Water has numerous dissolved compounds (for example, bicarbonate ion (HCO3), which can readily "combine" with copper and remove copper from solution. Copper can also be taken up by living organisms, including bacteria, algae, and brine shrimp, and it can bind to substrates in the system (including activated carbon) (Cardeilhac and Whitaker 1988). Still other factors can cause the copper concentration to rise too high. Increases in salinity will decrease the binding (absorption) of copper to surfaces. In salt water at more neutral pH (e.g., $\mathrm{pH}$ of around 7), copper is surrounded by chloride molecules. Decreases in $\mathrm{pH}$ will release previously bound copper, and increase levels in solution, thereby increasing the risk of toxicity. Also, if some live foods, such as brine shrimp, are present during copper treatments, they may bioaccumulate enough copper to be toxic to fish that eat them (Cardeilhac and Whitaker 1988).

\section{Materials And Methods}

To assess the haematological profile of the control and treated fish, hemoglobin, RBC and WBC counts were measured in the whole blood of Cyprinus carpio. The changes in physico-chemical characteristics, such as temperature, $\mathrm{pH}$, dissolved oxygen, alkalinity, hardness, salinity, calcium and magnesium of experimental water were recorded throughout the experimental period. Fresh water fish Cyprinus carpio, weighing 5.0-6.0 gm and measuring 7-8 cm were collected from Tamilnadu Fisheries Development corporation, Aliyar fish farm, Aliyar, Tamilnadu, India. Fish of same age and size which hatched from the same lot of eggs were collected, the age of the fish being 2 to 3 months old. They were safely brought to the laboratory in well packed polythene bags containing aerated water and stocked in a large cement tanks (36' x18'x19'). Fish were acclimatized for about 20 days before the commencement of the experiment. During acclimatization period, fish were fed with ad libitum, with rice bran and ground nut oil cake in the form of dough once in daily. Water replaced every $24 \mathrm{~h}$ after feeding in order to maintain a healthy environment for the fish. This ensures sufficient oxygen supply for the fish and the environment is devoid of any accumulated metabolic waste. The feeding was withheld for $24 \mathrm{~h}$ before the commencement of the experiment and to keep the specimens in the same metabolic state. The fish were introduced into glass aquarium $\left(26^{\prime} \times 18^{\prime} \times 18.5^{\prime}\right) \mathrm{cm}$ which was washed thoroughly and maintained in the laboratory. Separate circular plastic tubs of 50 litres of water capacity were taken and different concentrations of copper were added. 10 healthy fishes were introduced into each tub. A control tub (no toxicant) with 50 litres of water and 10 fishes were also maintained. Three replicates were maintained for each concentration groups. The mortality/ survival of fish in control and copper treated tubs was recorded after $24 \mathrm{~h}$ and the concentration at which $50 \%$ mortality of fish occurred was taken as the median lethal concentration (Lc50) for $24 \mathrm{~h}$ which was $0.24 \mathrm{ppm}$. A similar experimental set up was also maintained to determine the median lethal concentration of copper to fish Cyprinus carpio for $96 \mathrm{~h}$. The test water was renewed at the end of $24 \mathrm{~h}$ and freshly prepared solution was added to maintain the concentration of copper at a constant level. The median lethal concentration (Lc50) of copper sulphate for $96 \mathrm{~h}$ was found to be $0.12 \mathrm{ppm}$. The median lethal concentration of copper was calculated by Probit analysis method (Finney,1978). The sublethal toxicity was conducted at $1 / 10^{\text {th }}$ of Lc50 of $24 \mathrm{~h}$ value $(0.024) \mathrm{ppm}$.

\section{Estimation Of Haemoglobin}

Hemoglobin content of the blood was estimated by Cyanmethemoglobin method (Drabkin, 1946) using Diagnostic Reagent kit supplied by Monozyme India Ltd.

\section{Principle}

Hemoglobin can undergo several reactions; it binds with oxygen and carbon monoxide to from oxy hemoglobin and carboxy hemoglobin, respectively. Oxidation of the fesrrous ion to the ferric form results in the formation of methemoglobin. Methemoglobin binds cyanide ions to form cyanmethaemoglobin. Hemoglobin can be measured in any of these forms, but the most satisfactory method of assay from the view point of accuracy and simplicity involves the conversion of all forms of blood hemoglobin to cyanmethaemoglobin.

$$
\text { Hemoglobin }+\mathrm{K} 3 \mathrm{Fe}(\mathrm{CN}) 6 \longrightarrow \text { Methemoglobin }
$$


Methemoglobin $+\mathrm{KCN}$

Cyanmethermoglobin

The brownish colored cyanmethemoglobin is the product of almost all form of hemoglobin found in blood except Hbs and can be measured at $540 \mathrm{~nm}$. The colour intensity at this wavelength is proportional to the total hemoglobin concentration.

\title{
Reagents
}

\author{
Reagents 1: Hemoglobin reagent \\ Reagents 2: Hemoglobin standard $(15 \mathrm{~g} / \mathrm{dl})$
}

\section{Procedure}

Four tests tubes were taken and marked as Blank (B), Standard (S), Tests (T) and control (C). To the test tube which marked as test (T) and control (C) $5.0 \mathrm{ml}$ of hemoglobin reagent (Reagent-1) was added. Then, $0.02 \mathrm{ml}$ of blood drawn from metal exposed fish and control fish was dropped in the respective tubes. The given hemoglobin standard reagent (Reagent-2) was taken in the test tube marked as standard (S), control (C) and test (T) against Blank (B) was measured at $540 \mathrm{~nm}$ using spectrophotometer (Spectronic 20D ${ }^{+}$Milton Roy, USA).

\section{Calculation}

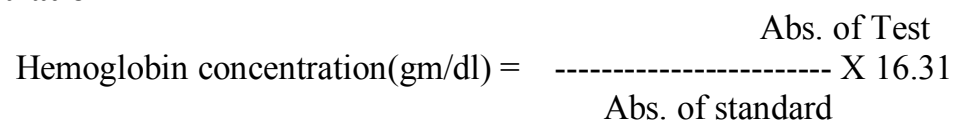

\section{Erythrocyte Count}

Erythrocytes were counted by the method of Rusia and Sood ( 1992 ) using haemocytometer.

\section{Principle}

The blood specimen is diluted with red cell diluting fluid which does not remove the white cells but allow red cells to be counted in a known volume of fluid. Finally, the number of cells in undiluted blood is calculated and reported as the number of red cells per cubic millimeter of whole blood.

\section{Procedure}

Blood was drawn in a clean RBC pipette up to its 0.5 mark. The tip of the pipette was wiped clean and dipped vertically into the red cell diluting fluid, which was then gently sucked up to mark 101 . Then the tip of the pipette was closed with a finger and the contents were mixed thoroughly by shaking the pipette at right angles to its long axis. The red bead in the bulb helps for proper mixing of blood with the diluting fluid.

The counting chamber of the haemocytometer was washed with distilled water, covered with a clean special cover glass and focused under a compound microscope. The ruled area of the haemocytometer was located clearly. Then the first drop of the fluid in the pipette was discarded by holding the pipette at $450 \mathrm{~nm}$. The tip of the pipette was touched between the cover slip and the counting chamber and the diluted blood was applied by blowing. The blood was drawn into the chamber was left as such for 3 minutes to allow the cells to settle down.

\section{Counting}

The slide was first examined under low power and then under high power magnification. The counting chamber of the haemocytometer has a central heavy ruled area of $1 \mathrm{sq}$. mm. This central area is RBC counting chamber. It is divided into 25 squares and each square is sub-divided into 16 small squares. For the erythrocyte count, the cells falling with in and those touching the right and upper margin of the four corner squares and the central square ( 8.0 small squares ) were counted. The total number of erythrocytes per cubic millimeter of whole blood was then calculated.

\section{Calculation}

No. of erythrocyte X Dilution counted erythrocytes $=$ (million/cu.mm of blood)

No. of
Dilution
Area counted -5 X $0.04=0.2$ square $\mathrm{mm}$
Depth of fluid $-0.1 \mathrm{~mm}$ Area counted X Depth of fluid

\section{Leucocyte Count}

Leucocytes were counted by the method of Rusia and sood (1992) using haemocytometer. 
Principle

Blood is diluted with acid solution which removes the red cells by haemolysis and also accentuates the nuclei of the white cells, thus the counting of the white cells become easy. Counting is done with a microscope under low power and knowing the volume of fluid examined and the dilution of the blood, the number of white cells per cubic millimeter in undiluted whole blood is calculated.

\section{Procedure}

Blood was drawn up to the 0.5 mark using a clean WBC pipette. Then the pipette was immediately kept in a watch glass containing WBC diluting fluid and it was drawn up to mark, taking care that no air bubbles included. The contents were mixed well by rotating the pipette between the palms of the hands. The white bead in the pipette helps for proper mixing of blood with the diluting fluid. The diluted blood was allowed to stand as such for 3 minutes for haemolysis of red cells to occur. Again the contents were mixed by rotating the pipette.

After discarding the first few drops of diluted blood the counting chamber of the haemocytometer was charged with the fluid making sure that no air bubble were trapped between the cover slip and the chamber. The cells were allowed to settle down for a minute.

\section{Counting}

For the counting of leucocytes, the slide was examined under low power magnification of microscope. The neubaur's counting chamber is divided into two counting area which are ruled. Each counting chamber is divided into a total ruled area of 9 sq. $\mathrm{mm}$. The area of each square is 1 sq.mm area of the 4 corner slide was used for the counting of leucocytes. The cells falling within the four corners square were counted and the total number of leucocytes per cubic millimeter of whole blood was calculated.

\section{Calculation}

No. of leucocytes X Dilution method

$$
\text { leucocytes }=
$$

Area counted X Depth of fluid

No. of

Dilution $\quad-20$

Area counted - 4X 1 = 4 square.mm

Depth of fluid $-0.1 \mathrm{~mm}$

\section{Results}

Table 2 and Fig. 1 Reveal the changes in red blood cell count of the blood of fish Cyprinus carpio exposed to sublethal concentration of copper exposed fish for 35 days. The RBC count was decreased throughout the study period when compared to the control showing a minimum percent decrease of -2.22 at the end of $7^{\text {th }}$ day and a maximum percent decrease of 18.36 at the end of $35^{\text {th }}$ day. Decrease in RBC count in copper exposed for $7^{\text {th }}, 14^{\text {th }}, 21^{\text {st }}, 28^{\text {th }}$, and $35^{\text {th }}$ days, the percent observed was $-2.22,-6.52,-10.63,-14.58,-$ 18.36. Changes in the leucocyte count of fish Cyprinus carpio exposed to sublethal concentration of copper for 35 days were presented in Table 3 and Fig 2. During above exposure period WBC count was decreased throughout the study period showing a percent decrease of $-48.51,-53.09,-67.63,-70.43,-74.82$ at the end of $7^{\text {th }}, 14^{\text {th }}, 21^{\text {st }}, 28^{\text {th }}$, and $35^{\text {th }}$, days respectively. However, WBC count was declined showing a minimum percent decrease of -48.51 at the end of the $7^{\text {th }}$, and maximum percent decrease -74.82 at the end of $35^{\text {th }}$ day. Table 4 . and Fig 3. Represent the data on changes in the hemoglobin content of the fish Cyprinus carpio exposed to sublethal concentration of copper for 35 days. The hemoglobin content in the copper exposed fish was found to be decreased when compared to the control showing a percent decrease of $-15.64,-26.59,-25.60,-23.36,-11.73$ for $7,14,21,28,35$ days. However, this results shows a minimum percent decrease at $35^{\text {th }}$ day, showing a percent decrease of -11.73 and a maximum percent decrease at $14^{\text {th }}$ day showing a percent decrease of -26.59 in copper exposed fish.

Table 2. Changes in the red blood cell (RBC) count of Cyprinus carpio exposed to sublethal concentration of copper for 35 days

\begin{tabular}{|c|c|c|c|c|c|}
\hline S.NO & $\begin{array}{c}\text { EXPOSURE } \\
\text { PERIOD }\end{array}$ & CONTROL & EXPERIMENT & $\begin{array}{c}\text { CHANGE } \\
\%\end{array}$ & -2.22 \\
\hline 1 & 7 & $0.90 \pm 0.71$ & $0.88 \pm 0.71$ & -6.52 & -1.6 \\
\hline 2 & 14 & $0.92 \pm 0.96$ & $0.86 \pm 0.96$ & -10.63 & 0.03 \\
\hline 3 & 21 & $0.94 \pm 1.01$ & $0.84 \pm 0.71$ & -14.58 & -0.35 \\
\hline 4 & 28 & $0.96 \pm 0.71$ & $0.82 \pm 0.71$ & -18.36 & -0.07 \\
\hline 5 & 35 & $0.98 \pm 0.31$ & $0.80 \pm 0.71$ & \\
\hline
\end{tabular}


Values are mean \pm S.E. of five individual observations. (-) Denotes percent decrease over control.

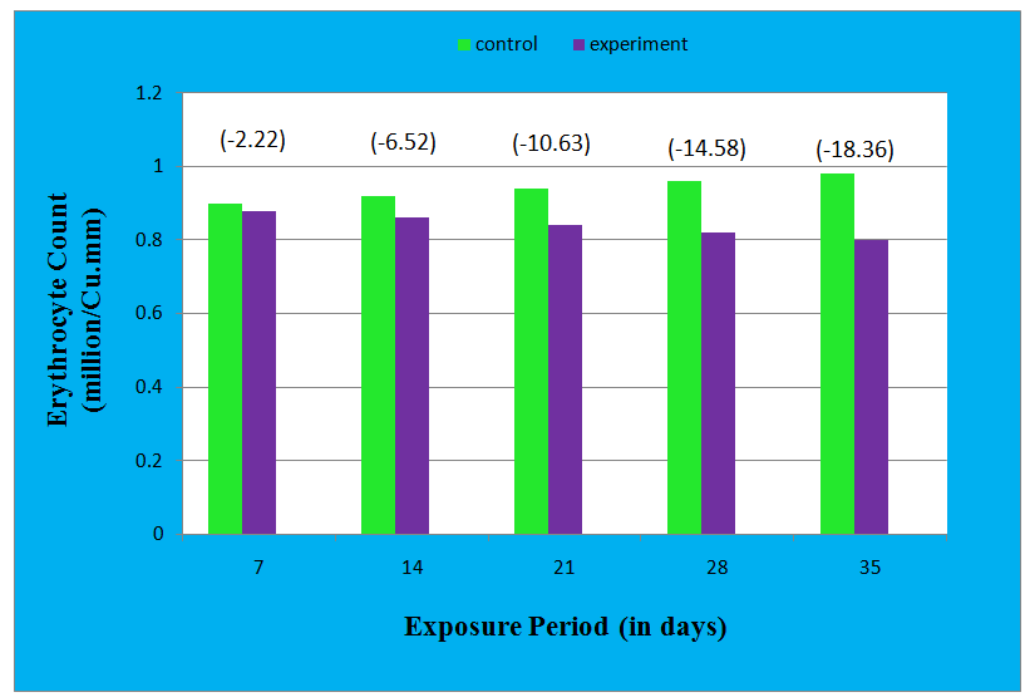

Fig.1

Fig. 1. Erythrocyte count of Cyprinus carpio exposed to sublethal concentration of copper for 35 days. Error bars indicate the standard error of the mean.

Table 3. Changes in the white blood cell (WBC) count of Cyprinus carpio exposed to sublethal concentration of copper for 35 days

\begin{tabular}{|c|c|c|c|c|c|}
\hline S.NO & $\begin{array}{c}\text { EXPOSURE } \\
\text { PERIOD }\end{array}$ & CONTROL & EXPERIMENT & $\begin{array}{c}\text { CHANGE } \\
\%\end{array}$ & $\begin{array}{c}\text { CALCULATED } \\
\text { t VALUE }\end{array}$ \\
\hline 1 & 7 & $20.57 \pm 0.75$ & $10.59 \pm 0.55$ & -48.51 & -0.52 \\
\hline 2 & 14 & $19.06 \pm 0.70$ & $8.94 \pm 0.57$ & -53.09 & -0.37 \\
\hline 3 & 21 & $18.51 \pm 0.46$ & $5.99 \pm 0.39$ & -67.63 & 0.07 \\
\hline 4 & 28 & $19.01 \pm 0.71$ & $5.62 \pm 0.50$ & -70.43 & 0.19 \\
\hline 5 & 35 & $18.23 \pm 0.58$ & $4.59 \pm 0.52$ & -74.82 & 0.33 \\
\hline
\end{tabular}

Values are mean \pm S.E. of five individual observations. $(+)$ Denotes percent increase over control. (-) Denotes percent decrease over control.

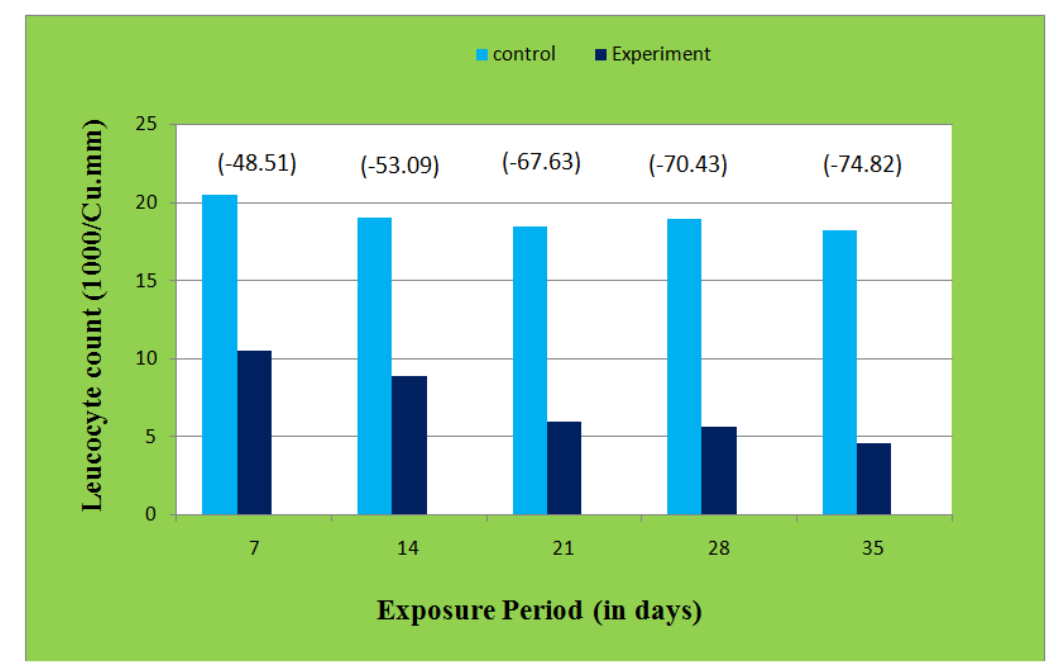

Fig. 2. Leucocyte count of Cyprinus carpio exposed to sublethal concentration of copper for 35 days. Error bars indicate the standard error of the mean 
Table 4. Changes in the hemoglobin content of Cyprinus carpio exposed to sublethal concentration of copper for 35 days

\begin{tabular}{|c|c|c|c|c|c|}
\hline S.NO & $\begin{array}{c}\text { EXPOSURE } \\
\text { PERIOD }\end{array}$ & CONTROL & EXPERIMENT & $\begin{array}{c}\text { CHANGE } \\
\%\end{array}$ & $\begin{array}{c}\text { CALCULATED } \\
\text { t VALUE }\end{array}$ \\
\hline 1 & 7 & $5.56 \pm 1.03$ & $4.69 \pm 0.51$ & -15.64 & -1.37 \\
\hline 2 & 14 & $5.34 \pm 0.88$ & $3.92 \pm 0.64$ & -26.59 & -1.06 \\
\hline 3 & 21 & $4.96 \pm 0.72$ & $3.69 \pm 0.48$ & -25.60 & -1.11 \\
\hline 4 & 28 & $3.98 \pm 0.70$ & $3.05 \pm 0.31$ & -23.36 & -1.16 \\
\hline 5 & 35 & $3.41 \pm 0.51$ & $3.01 \pm 0.31$ & -11.73 & -1.48 \\
\hline
\end{tabular}

Values are mean \pm S.E. of five individual observations. $(+)$ Denotes percent increase over control. (-) Denotes percent decrease over control.

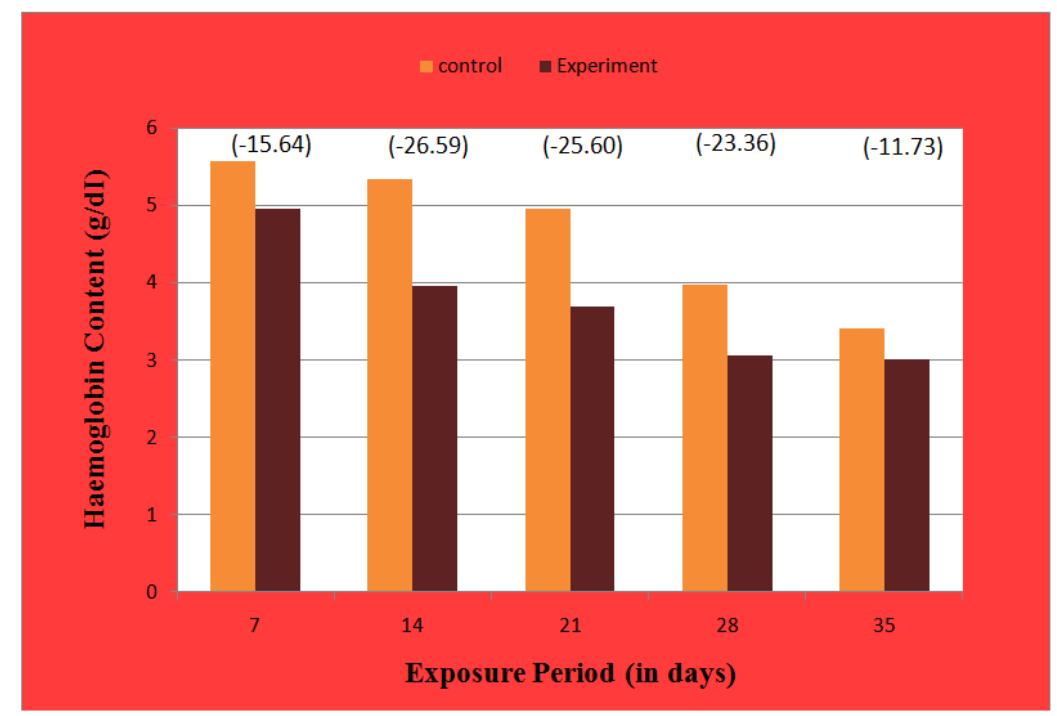

Fig.3.

Fig. 3. Haemoglobin of Cyprinus carpio exposed to sublethal concentration of copper for 35 days. Error bars indicate the standard error of the mean.

\section{Discussion}

Copper is trace nutrient that is required in small amounts (5-20 micrograms per gram $(\mu \mathrm{g} / \mathrm{g}))$ by humans, other mammals, fish and metabolism and the functioning of more than 30 enzymes. It is also needed for the formation of haemoglobin and haemocyanin, the oxygen-transporting pigments in the blood of vertebrates respectively. However, copper concentrations that exceed 20 micrograms per gram $(\mu \mathrm{g} / \mathrm{g}) \mathrm{can}$ be toxic, as explained by Bradl and Heike (2005) and Wright and Welbourn (2002). Copper has been known to humans for at least 6000 years. Its uses in alloys, tools, coins, jewellery, food and beverage containers, automobile brake pads, electrical wiring and electroplating reflect its malleability, ductility and electrical conductivity. The use of copper to kill algae, fungi and molluscs demonstrates that it is highly toxic to aquatic organisms. In fact, copper is one of the most toxic metals to aquatic organisms and ecosystems. This is one of the reasons that environmentally sensitive mining practices are so important. Fish are 10 to 100 times more sensitive to the toxic effects of copper than mammals. Several authors, including Forstner and Wittman (1979), Hodson (1979) and Wright and Welbourn (2002), have demonstrated. This is an exception to the general principle that aquatic animals are more sensitive than aquatic plants to the toxic effects of metals (Okocha and Adedeji 2012).

Copper, an essential trace metal for cellular metabolism, may become extremely toxic for aquatic animals as its concentration in water increases. The important natural sources of copper are the multiple human activities (industries, agriculture, harbors) have considerably increased the input of this metal in estuarine and marine environments around the world (Flegal 1993 and D'Adamo 2008). At equilibrium, there are few free copper ions in natural waters since most copper is associated with inorganic ions or organic substances. However, $\mathrm{CuSO}_{4}$ has been widely used to control algae and some pathogens in fish culture ponds, increasing copper concentration in water. $\mathrm{CuSO}_{4}$ is highly toxic to fish, so the concentrations required to control algae or pathogen agents must be below the toxicity threshold for fish. The effect of $\mathrm{CuSO}_{4}$ on fish has been studied exhaustively and, as expected, some species have been found to be more susceptible to copper than 
others. This implies previous knowledge of the susceptibility of a given cultured fish species before using $\mathrm{CuSO}_{4}$. Hematological parameters are important for toxicological research, environmental monitoring and as indicators of disease and environmental stress. Many studies have demonstrated changes in blood variables as a result of environmental conditions and presence of contaminant (Azarin et al., 2012).

Fish exposed to environmental pollutions exhibit a variety of physiological response, including blood balance disturbances, ion regulatory disturbances, oxygen uptake and assess health status, since blood is an indicator of the physiological condition of animals. Hematological analysis and assessment blood plasma are useful in monitoring the physiological status of fish and as indicators of the health of the aquatic environment, although they are not routinely used in fish disease diagnosis. Blood parameters are often measured when clinical diagnosis of fish physiology is applied to determine the sublethal concentration effects of pollutants. Large concentrations of $\mathrm{CuSO}_{4}$ alter the blood parameters and immunosuppression can also be observed, due to the fact that monocytes and neutrophils are sensitive to heavy metals. Because fish are an important food resource and a major ecosystem component, it is important to assess the effect of $\mathrm{Cu}$ in fish and aim to evaluate heavy metal toxicity stress symptoms in Cyprinus carpio fingerling blood during long-term exposure of sublethal concentration of $\mathrm{CuSO}_{4}$ (Azarin et al., 2012) .

In common-carp Cyprinus carpio (Witeska, 2005) and Prochilodus lineatus (Caravalho and Fernandes, 2006) the exposure to copper induces blood alterations, characterized by an increase on the hemoglobin concentration, and also red blood cells count increases. This fact may be attributed to a compensatory effect in response to oxygen transport capacity (Mazon et al ., 2002), in C. macropomum, it was observed that the number of red blood cells decreased after treatment. In Channa punctatus, $0.36 \mathrm{mg} \mathrm{L}-1$ copper sulfate reduced the number of red blood cells (Griffin et al ., 1999). This fact is explained because erythrocyte production by the hematopoietic organs decreases due to the destruction of circulating cells (Singh et al ., 2008). On the other hand, Williams \& Wootten (1981) related an increase in hematocrit of rainbow trout (Oncorhynchus mykiss) treated with $\mathrm{CuSO}_{4}$ for $24 \mathrm{~h}$, corroborating the results with the highest concentration $(8.75 \mathrm{mg} \mathrm{L}-1)$. The increase in erythrocyte volume caused by hypoxia situation, as reported by Tavares-Dias et al., 2002 in P. mesopotamicus. According to Nussey et al. (1995a, b) and Mazon et al. (2002), these alterations are attributed to the damage that copper causes in gills and hematopoietic organs. Although copper is an essential element to fish, it needs to be carefully used for treatment or prophylaxis. When the copper concentration exceeds the tolerating level, fish may be acutely or chronically affected. The measurement of hematological changes in blood of fish exposed to the toxicant may be used to predict the toxic effects of toxicant. Copper stress is known to induce changes in the blood parameters of fish. Most changes in blood cells express in interference in the ionic status and fluid volume (Tavares-Dias et al.,2011).

According to Pamila et al., 1991. the reduction in hemoglobin concentration in fish exposed to toxicant could also be due to the inhibitory effect of the toxic substance on the enzyme system responsible for synthesis of $\mathrm{Hb}$. Joshi et al., 2002 suggested that heavy metal exposure also decreased the $\mathrm{RBC}, \mathrm{Hb}$ concentration due to impaired intestinal absorption of iron. The anemia might have led to a fall in the $\mathrm{RBC}, \mathrm{Hb}$ concentration volume. Anemia, under copper induced stress, may also be due to blood cell injury and disrupted $\mathrm{Hb}$ synthesis. The anemic condition in fish results from an unusually low number of RBC or too little hemoglobin in the red blood cells. Anemia is an early manifestation of acute and chronic intoxication of heavy metals. Significance of these changes may be understood in terms of reduced oxygen consumption in fish resulting in death due to heavy metal pollution. In other hand, increased hemoglobin levels and elevated numbers of erythrocytes have been observed in brook trout (Salvelinus fontinalis) after 21 days of $\mathrm{CuSO}_{4}$. Also in common carp Cyprinus carpio (Witeska et al.,2005) and Prochilodus lineatus . The exposure to copper induces blood alterations, characterized by an increase on the $\mathrm{Hb}$ and $\mathrm{RBC}$ concentration. These negative results can be also due to the different concentrations and times used in the treatments, as wells as to the physicochemical parameters of water and the monogenean species sensibility to $\mathrm{CuSO}_{4}$. Similar results were found in Channa punctatus that exposure to sublethal concentration of $\mathrm{CuSO}_{4}$ and reduced the $\mathrm{RBC}, \mathrm{Hb}$ concentration.. In C. macropomum, it was observed that the number of $\mathrm{RBC}$ decreased after treatment with various concentrations $\mathrm{CuSO}_{4}$ (Griffin et al.,1999).

Significant increase of WBC concentration in fish submitted to 0.04 and $0.004 \mathrm{mg} / \mathrm{L} \mathrm{CuSO}$ than to control groups was found. One of the most elementary ways to assess the immune system is to explore changes in the WBC count and its types (Moraes et al.,2007). High levels of WBC counts indicate damage due to infection of body tissues, severe physical stress and as well. In most cases, abnormal red cell morphology is noted Singh et al.,2008 and Carvalho and Fernandes (2006) showed that various concentrations of $\mathrm{CuSO}_{4}$ increased the number of WBC. Similar findings were also documented significantly higher in fish exposed to increased copper concentration (Azarin et al.,2012). WBC are the primary line of immune defense. One of the most elementary ways to assess the immune system is to explore changes in the white blood cell count and its types (Tavares-Dias and Moraes, 2007). Therefore, the immune system response to copper sulfate appears to be related to modulation of the immune system. In C. macropomum examined in this study leukocytes features 
were similar and described by, Tavares-Dias et al . (1999) for this same species. However, some neutrophils and eosinophils here were found with toxic granulations that indicate high production of its contents. Witeska and Wakulska (2007) reported that phagocytes (neutrophils and monocytes) are sensitive to heavy metal intoxication ( Tavares-Dias et al.,2011). In this assay using juveniles C. macropomum, increased $\mathrm{CuSO}_{4}$ concentrations caused leucopenia, characterized by a low number of lymphocytes, neutrophils and PAS-GL. Similarly, in P. mesopotamicus exposed to low concentration of copper sulfate, reduced number of lymphocytes was reported by Tavares-Dias et al. (2002). Stress response is known to cause changes on the immune system. On this point of view, in a situation of monocytopenia and neutropenia in O. mossambicus, the migration and phagocytic activity in the gills, liver and kidney are disrupted by exposure to copper (Nussey et al ., 1995c). On the contrary, leukocytosis with increase in the lymphocytes and eosinophils numbers was followed by decrease in the numbers of monocytes and basophils in C. punctatus (Singh et al., 2008). Leukocytosis has been attributed to an increase in leukocyte to protect the organism against infections in copper-damaged tissue (Mazon et al ., 2002).

In juveniles C. macropomum, since $4.37 \mathrm{mg} / \mathrm{L}-1$ of $\mathrm{CuSO}_{4}$ showed $99.3 \%$ of efficacy in the treatment against monogenoideans A. spathulatus, therefore concentrations between 5.0-6.0 mg L-1 may be sufficient for eliminating these parasites, in the trial conditions used here. Short-term exposure to sublethal $\mathrm{CuSO}_{4}$ causes physiological alterations affecting the osmotic imbalance. Furthermore, higher $\mathrm{CuSO}_{4}$ concentration also causes severe immunosuppression in fish, which may make the organism susceptible to diseases. Blood parameters of C. macropomum may be used safely as a tool in field for monitoring the contamination caused by this heavy metal Tavares-Dias et al., 2012. In recent years, haematological variables were extensively used when clinical diagnosis of fish physiology was applied to determine the effects of external stressors and disease conditions in fish (Hodson et al., 1978; Dhillion and Gupta, 1983; Benerjec and Kamar, 1988). This, according to Gill and Pant (1981), is as a result of their relationship with energetic (metabolite levels),respiration mechanics (hematological levels) and defence mechanisms (leucocyte levels). Hematological parameters provide an integrated measure of the health status of fishes. The introduction of toxicants into an environment, where fishes are found, stuns them and/or acts as a stressor of the fish and organisms found in the environment (Olatayo, 2008). The introduction of a toxicant to an aquatic system might decrease the dissolved oxygen concentration, which will impair respiration thus leading to asphyxiation (Warren, 1977). Stickney(1977) also reported that insufficient amount of dissolved oxygen is one of the contributory factors of mortality in some fish species. The darkening of the fish skin, respiratory distress and erratic swimming can be observed when fishes are exposed to acute concentrations of toxicants (DeSilva and Ranasingle, 1989; Ayuba and Ofojekwu,2002).

In this study, the main hematological response of Cyprinus carpio fingerling to the sublethal concentration of $\mathrm{CuSO}_{4}$ was a significantly lower, and decrease in the $\mathrm{RBC}, \mathrm{WBC}, \mathrm{Hb}$, than to the control group. Unlike mammals, the hematopoietic system of fish is mainly located in the interstitium of the kidney. So, a reduction in the hematological parameters may be attributed to the malfunctioning of the hematopoietic system caused by morphological alterations in renal interstitium. Additional, the hematological parameters changes can be interpreted as a compensatory response that improves the oxygen carrying capacity to maintain the gas transfer and a change in water blood barrier for gas exchange in gill lamellae

\section{Conclusion}

The CuSO toxicity may also vary significantly among fish species due to other factors such as fish size, exposure dose and time, species unique mechanisms for the metabolism of copper ion (De Boeck et al., 2004) and physiological conditions of the individuals and also water physicochemical parameters. Thus, it is concluded that the hematological parameters are the most sensitive parameters in monitoring the toxicity of copper especially at sublethal concentrations and changes in hematological variables in response to copper exposure indicate ionoregulatory or respiratory disturbances that imply an increase in energy consumption to restore homeostasis instead of other physiological functions and weight gain and growth. The blood parameters of Cyprinus carpio exposed to copper sulfate showed ionoregulatory interference, but also compensatory responses to allow fish to endure and showed that a changes significantly affected hematology of Cyprinus carpio.

\section{Reference}

[1]. Livingstone, D., R. (2003): Oxidative stress in aquatic organ- ism in relation to pollution and agriculture. Revue de Medecine Veterinaire $154,427-430$

[2]. Luoma, S., N., Rainbow, P., S. (2008a): Sources and cycles of trace matals. In: Metal Contamination in Aquatic En- vironments: Science and Lateral Management. Cam- bridge University Press, Cambridge. 47-66.

[3]. Jezierska, B., Witeska, M. (2001): Summary of metal-in- duced disturbances in fish organisms. In: Metal Toxic- ity to Fish. Wydawnictvo Akademii Podlaskei, Siedlce. 214-243.

[4]. Kamunde, C., Clayton, C., Wood, C.,M. (2002): Waterborne vs. dietary copper uptake in rainbow trout and the effects of previous waterborne copper exposure. American Journal of Physiology - Regulatory, Integra- tive and Comparative Physiology 283, R69R78. 
[5]. Tao, S., Wen, Y., Long, A., Dawson, R., Cao, J., Xu, F. (2001). Simulation of acid-base condition and copper specia- tion in fish gill microenvironment. Computers and Chemistry 25, 215-222.

[6]. Roja Sadat Jalali Mottahari, 2013. Impact of Copper Sulphate on Hematological and Some Biochemical Parameters of Common Carp (Cyprinus carpio L., 1758)

[7]. In Different pH World Journal of Fish and Marine Sciences 5(5): 486- 491, ISSN 2078-4589 (C) IDOSI Publications, 2013 DOI.

[8]. Nussey, G., Van-Vuren, J., H., J. DU Preez, H.,H.1995a. Effect of copper on blood Osmoregulation of the Mozambique tilapia, Oreochromis mossambicus (Cichlidae). Comparative Biochemistry and Physiology, New York, 111C : 369-380.

[9]. Nussey, G., Van-Vuren, J., H., J. DU Preez, H., H. 1995b. Effect of copper on blood coagulation of Oreochromis mossambicus (Cichlidae). Comparative Biochemistry and Physiology, New York, 111C : 359-367.

[10]. Nussey, G.,Van-Vuren, J., H., J. DU Preez, H., H. 1995c. Effect of copper on the differential white blood cell counts of the Mozambique tilapia (Oreochromis mossambicus). Comparative Biochemistry and Physiology, New York, 111C : 381-388.

[11]. Mazon, A., F. Monteiro, E., A., S., Pinheiro, G.,H.D., Fernandes, M.,N.2002.

[12]. Hematological and physiological changes induced by Short-term exposure to copper in the freshwater fish, Prochildus scrofa.

[13]. Brazilian Journal of Biology, São Carlos, 62: 621-631.

[14]. Figueiredo-Fernandes, A.; Ferreira- Cardoso, J. V.; Garcia-Santos, S.; Monteiro, S.M.; Carrola, J.; Matos, P.; Fontainhas-Fernandes, A. 2007

[15]. Histopathological Changes in liver and gill epithelium of Nile tilapia, Oreochromis niloticus, exposed to waterborne copper. Pesquisa Veterinária Brasileira, Rio de Janeiro, 27 : 103-109.

[16]. Tavares-Dias, M. Martins, M., L. Schalch, S., H., C. Onaka, E., M. Quintana, C., I., F. Moraes, J., R., E. Moraes, F., R. 2002. Alteracoes hematologicase histopatológicas em pacu, Piaractus mesopotamicus, Holmberg, 1887

[17]. (Osteichthyes, Characidae), tratado com sulfato de cobre (CuSO 4). Acta Scientiarum, Maringá, 24 : $547-554$.

[18]. Carvalho, C.S., and Fernandes, M.N., 2006. Effect of temperature on copper toxicity and hematological responses in the Neotropical fish Prochilodus scrofa at low and high pH. Aquaculture, Amsterdam, $251: 109-117$.

[19]. Singh, D. Nath, K. Trivedi, S., P. Sharma, Y., K. 2008. Impact of copper on haematological profile of freshwater fish, Channa punctatus. The Journal of Environmental Biology , Lucknow, 29 : 253-257.

[20]. Witeska, M. and Wakulska, M. 2007 The effects of heavy metals on common carp white blood cells in vitro . Alternatives to Laboratory Animals, Baltimore, $35: 87-92$.

[21]. Adhikari, S., 2003.Effects of calcium and magnesium hardness on acute copper toxicity to Indian major carp, Labeo rohita (Hamilton) and catfish Channa punctatus (Bloch). Aquaculture Research Oxford, 34 : 975-980.

[22]. Booth, C.E., D.G., Mcdonald, B.P., Simons and M., Wood, 1988. Effects of aluminum and low pH on net ion fluxes and ion balance in the brook trout, salvelinus fontinalis. Fisheries and Aquatic Science, 45: 1563-1574.

[23]. Sudova, E., V. Piackova, H. Kroupova, M. Pijacek, and Z. Svobodova, 2009. The effect of praziquantel applied per os on selected haematological and biochemical indices in common carp, Cyprinus carpio. Fish Physiology and

[24]. Biochemistry, 35: 599-605.

[25]. Griffin, R.,B.; Davis, B.K.; Schlenk, D. 1999 Effect of simulated copper Sulphate therapy stress indicators in channel catfish. Journal Of Aquatic Animal Health, Oxford, $11: 231-236$.

[26]. Svobodova, Z., Vykusova, B. and Machova, J. 1994. Suble- thal chronic effects of pollutants on freshwater fish. Ed. R. Muller ir R. Lloyd. Lugano, 39-52 pp.

[27]. Van Vuren J.H.J., M.Van der Merwe and Du Preez H.H. 1994. The effect of Copper on the blood chemistry of Clarias garlepinus (Clariidae). Ecotox. Environm Safety 29: 187-199.

[28]. Singh, H., S. and Reddy, T., V. 1990. Effect of copper sulfate on hematology,blood Chemistry and hepato-somatic index of an Indian catfish, Heteropneustes (Bloch), and its recovery. Ecotoxicol. Environ. Saf. 20: 30-35.

[29]. Mishra, S., and Srivastava, A.,K. 1980. The acute toxic ef- fects of copper on the blood of a teleost. Ecotoxicol. Environ. Saf. 4: 191-194.

[30]. Cyriac, P.J., Antony, A. and Nambisan, P.N.K., 1989. Hemo- globin and haematocrit values in the fish, Oreochro- mis mossambicus (Peters) after short term exposure to copper and mercury. Bull. Envirn. Contam. Toxicol. 43: 315-320.

[31]. Vosylienë, M., Z. 1996. Haematological parameters of rain- bow trout (Oncorhynchus mykiss) during short-term exposure to copper. Ekologija 3:12-18.

[32]. Vosyliene, M., N.1996.The effect of long-term exposure to copper on physiological parameters of rainbow trout (Oncorhynchus mykiss). 2.Studies of haematological parameters. Ekologija 1: 3-6.

[33]. Van Vuren, J., H., J. M.Vander Merwe, and Du Preez, H.,H. 1994.The effect of copper on the blood chemistry of Clarias garlepinus (Clariidae).Ecotox. Environm. Safety 29: 187-199.

[34]. El-Domiaty, N.,A. 1987. Stress response of juvenile Clarias lazera elicited by copper. Comp. Bioch. and Physiol. C88 (2): $259-262$.

[35]. Dick, P.,T. and Dixon, D.,G. 1985. Changes in circulating blood cell levels of rainbow trout, MSalmo gairdneri Ri- chardson, following acute and chornic exposure to copper. J. Fish Biol. 26: 475-481.

[36]. McKim, J., M. Christensen G.,M. Hunt, E.,P. 1970. Changes in the blood of brook trout (Salvelinus fontinalis) after short-term and long-term exposure to copper. J. Fish. Res. Bd Can. 27: 1883-1889.

[37]. Christensen, G.M., McKim, J.M., Brungs, W.A., and Hunt, E.P., 1972. Changes in the blood of the brown bullhead (Ictalurus nebulosus Lesuer) following short and long term exposure to copper. Toxicol. App. Pharmacol. 23: 417-427.

[38]. Dethloff G.,M. and Bailey H.,C. 1998. Effects of copper on immune system parameters of rainbow trout (Oncor- hynchus mykiss). Environ. Toxicol. Chem.1 (9): 1807- 1814.

[39]. Grosell, M.; Nielsen, C.; Bianchini, A. 2002 Sodium turnover rate determines sensivity to acute copper and silver exposure in freshwater animals. Comparative Biochemistry and physiology, New York, 133C : 287-303.

[40]. Cardeilhac, P.T., and B.R., Whitaker, 1988. Copper treatments: uses and precautions. In Tropical fish Medicine. Stoskopf, M.K., ed. The veterinary clinics of North America: Small Animal Practice 18(2): 435-448.

[41]. Finney, D.J., 1978. Statistical Method in Biological Assay ( $3^{\text {rd }}$ Ed), Cambridge University Press, London, pp. 508.

[42]. Drabkin, D.L., 1946. Spectrometric studies, XIV-The crystallographic and optimal properties of the hemoglobin of man in comparison with those of other species.J. Biol. Chem., 164,703-723.

[43]. Bradl, Heike, (2005). Heavy Metals in the Environment: Origin, Interaction and Remediation.

[44]. Elsevier/Academic Press, London.

[45]. Wright and Welbourn 2002. Environmental Toxicology. Cambridge University Press, Cambridge, U.K. Forstner, U. and G.,T., W. Witmann (1979). Metal Pollution in the Aquatic Environment. Springer- Verlag, Berlin.

[46]. Hodson, P.V., U. Borgmann and H. Shear (1979). "Toxicity of Copper to Aquatic Biota.” In: Nriagu, J.O., ed., Biogeochemistry of copper, Part II. Health Effects. 
[47]. John Wiley and Sons, New York, N.Y., pp. 307-372.

[48]. Okocha, R., O. and Adedeji, O., B. 2012. Overview of copper toxicity to aquatic life.Veterinary Public Health and Preventive Medicine University of Ibadan, Nigeria Report and Opinion 2012;4:(8)

[49]. Flegal, A.,R. and S.,A. Sanudo-Wilhelmy, 1993. Comparable levels of trace metal contamination in two semi enclosed embayments: San Diego Bay and south San Francisco Bay. Environmental Science and Technology, 27:1934-1936.

[50]. D’Adamo, R., M. Di Stasio, A., Fabbrocini, F., Petitto, L., Roselli, and M.G.,Volpe, 2008.

[51]. Migratory crustaceans as biomonitors of metal pollution in their nursery areas, The Lesina lagoon (SE Italy) as a case stud. Environmental Monitoring and Assessment, 143: 15-24.

[52]. Azarin, H., Reza Imanpour, M., Rajabpour, M., 2012. Effect of Sublethal Levels of Copper Sulfate on Some Hematological Parameters of Rutilus frisii kutum Fingerlings, Global Veterinaria 9 (4): 479-485,

[53]. Witeska, M., 2005. Stress in fish: Hematological and 24: 165-171. Immunological effects of heavy metals. Electronic 53. Journal of Ichthyology, Berlim, 1: 35-41.

[54]. Williams, H., A. and Wootten, R. 1981. Some effects of therapeutic. levels of formalin and copper sulphate on blood parameters in rainbow trout. Aquaculture, Amsterdam, 24:341-353.

[55]. Tavares-Dias, M. Martins, M., L. Schalch, S., H., C. Onaka, E., M. Quintana, C., I., F. Moraes, J., R., E. Moraes, F., R. 2002. Alteracoes hematologicas e histopatológicas em pacu, Piaractus mesopotamicus, Holmberg, 1887

[56]. (Osteichthyes, Characidae), tratado com sulfato de cobre (CuSO 4). Acta Scientiarum, Maringá, 24 : 547-554.

[57]. Tavares-Dias, M., J., S. Ferreira, E., G. Affonso, E., A. Akifumi, Ono, M., L. Martins, 2011. Toxicity and effects of copper sulfate on parasitic control and hematological response of tembaqui, Colossoma macropomum. Boletim Instituto de Pesca. Sao Paulo, 34: 355-365.

[58]. Pamila ,D., P.A.Subbaiyan and M. Ramaswamy, 1991. Toxic effect of chromium and cobalt on Sartherodon mossambicus. Indian journal of Envtronmental Health, 33: 218-224.

[59]. Joshi, P., K., M. Bose and D. Harish, 2002. Hematological changes in the blood of Clarias battrachus exposed to mercuric chloride. Ecotoxicology and Environmental Monitoring, 12: 119-122.

[60]. Witeska, M., 2005. Stress in fish: Hematological and 24: 165-171. Immunological effects of heavy metals. Electronic 53. Journal of Ichthyology, Berlim, 1:35-41.

[61]. Moraes, F.R., 2007. Leukocyte and thrombocyte reference values for channel catfish ( Ictalurus punctatus Raf.), with an assessment of morphological, cytochemical, and ultrastructural features. Veterinay Clinical Pathology, Madison, $36: 49-54$.

[62]. Tavardes-Dias, M. and F., R. Moraes, 2007. Leukocyte and thrombocyte reference values for channel catfish, Ictalurus punctatus, with assessment of morphological, an assessment of morphological, cytochemical and ultra structural features. Veterinary Clinical Pathology, 54. Schlenk, D. J.L. Gollon and B.R.Griffin, 1998. Madison, 36:49-54.

[63]. Tavares-Dias, M., Sandrin, E., F., S. Campos- Filho, E. 1999. Caracteriticas haematological do tambaqui Colossoma macropomum Cuvier (Osteichthyes: Characidae) em sistema de monocultivo intensivo. II. Leucócitos. Revista Brasileira de Zoologia, Curitiba, 16:175-84.

[64]. Witeska, M. and Wakulska, M. 2007 The effects of heavy metals on common carp white blood cells in vitro . Alternatives to Laboratory Animals , Baltimore, $35: 87-92$.

[65]. Hodson, P.,V., Blunt, B.,R., and Spry D.,T. 1978. Chronic toxicity of water-borne lead and dietary lead to Rainbow trout, Salmo gairdneri in Lake Ontario. Wat. Res. 12:869-878.

[66]. Dhillion, S., S. and Gupta A., K. 1983. A clinical approach to study of pollution intoxication in freshwater teleost (Clarias berachus). Water, Air and Soil Pollut.20(1):61-63

[67]. Benerjec, V., and Kamar, K., 1988. Effect of zinc, mercury and cadmium on erythrocyte and related parameters in the fish Anabas tentudinius. Envir. Ecol. 3:739-781.

[68]. Gill A. and Pant J.1981. Effects of fire on plants and animals. Retrieved $11^{\text {th }}$ March, 2010.

[69]. Olatayo, V., S. 2008. Haematological responses of Oreochromis niloticus (Trevawas) exposed to various concentrations of poisonous extract from two local plants. Nig. J. Fisheries, 5(1):23-30.

[70]. Warren, C., E. 1977. Biology and Water Pollution Control. W.B. Sabders and Company, Philadelphia, USA. 434p.

[71]. Stickney, R., R. 1977. Principles of Warm Water Aquaculture. John Willey and Sons Incorp. U.K. 375p.

[72]. De Silva, C.,D. and Ranasingle J. 1989. Toxicity of four commonly used agrochemicals on Oreochromis niloticus (L) fry. Asian Fish. Sci.2:135-145.

[73]. Ayuba, V.O., and Ofojekwu, P.C., 2002. Acute toxicity of the root extract of jimson's weed Datura innoxia to the African catfish, C. gariepinus fingerlings. J,. Aquac. Sci. 17(2):131-133.

[74]. De Boeck, G., W. Meeus, W. De Coen and R. Blust, 2004. Tissue specific Cu bioaccumation patterns and differences in sensitivity to waterborne $\mathrm{Cu}$ in three freshwater fish: rainbow trout, Oncorhynchus mykiss, common carp,Cyprinus carpio. Aquatic Toxicology, New York, 70: 179-188. 